\title{
Theoretical approach to electrodiffusion of shallow donors in semiconductors: I. Stationary limit
}

\author{
N. I. Kashirina, V. V. Kislyuk, M. K. Sheinkman \\ Institute of Semiconductor Physics, NAS Ukraine, 45 prospekt Nauki, Kyiv, 252028, Ukraine \\ Phone/Fax: +044 26563 40; E-mail: moishe@photel.semicond.kiev.ua
}

\begin{abstract}
Analysis is made for the possibility of redistribution of mobile point defects in a semiconductor after its exposure to the electric field till the stationary conditions in the crystal are reached. Two different ways of applying the voltage are considered: (i) directly to the sample, (ii) to a capacitor, with the sample located between the plates. This model is applicable also to the electric field of any nature, whether external or internal, e.g. that arisning at the metal-semiconductor interface.
\end{abstract}

Keywords: Electrodiffusion, CdS, mobile donors.

Paper received 14.07.98; revised manuscript received 25.08.98; accepted for publication 27.10.98.

\section{Introduction}

Mobile point defects in semiconductors result in degradation of semiconductor devices. Mobile point defects in II-VI compounds are the principal reagent in photochemical reactions found to affect the photosensitivity [1] and luminescence of laser screens [2], to give rise to conducting channels [3] and to change the properties of metal-semiconductor junctions $[4,5]$. Since semiconductor devices are based mainly on p-n- or hetero-junctions, there always is an internal electric field to act on the mobile charged defects. Manufacturers of very large scale Si solar cells have a problem with the mobility of drifting interstitials, which is substantially high even at moderate temperatures [6].

The drift of mobile defects can be utilized to redistribute them, decreasing thereby their content within some part of a crystal $[7,8]$.

Cadmium sulfide is a non-stoichiometric compound with inhomogeneity diagram shifted to the excess of cadmium at room temperature [9]. The excess cadmium occupying interstitials (Cdi) in $\mathrm{CdS}$ is a shallow donor $\left(\mathrm{E}_{\mathrm{c}}-\mathrm{E}_{\mathrm{d}}=\right.$ $=0.03 \mathrm{eV}$ ) with a rather high mobility (activation energy about $0.4-0.6 \mathrm{eV})$ at moderate temperatures $(300-400 \mathrm{~K})$.

This paper presents a model which describes the final distribution of defects after exposure to the electric field. The model assumes a constant charge state of the drifting ions. This problem was considered for the case of cadmium sulfide.

\section{Theoretical background}

One-dimensional diffusion-drift equation was used for the electron subsystem in conjunction with Poisson's equation and Boltzmann distribution of charged $\mathrm{Cd}^{+}$ions (stationary conditions).

With $D_{n}$ being electron diffusivity, the electron current is expressed as:

$\vec{i}=-e n \mu_{n} \vec{\nabla} \varphi+e D_{n} \vec{\nabla} n$,

where $\varphi$ is the electric field potential, and $n$ is the electron concentration.

The singly charged mobile donors are distributed in accordance with the Boltzmann law:

$N_{C d}(x)=N_{C d}^{L} \exp \left\{-\frac{e \varphi(x)}{k T}\right\}$,

where $N_{C d}(x)$ is the concentration of Cd mobile interstitials. With boundary conditions: $N_{C d}(L)=N_{C d}^{L} ; \varphi(L)=0$ (cathode); $\varphi(0)=\varphi_{0}($ anode $)$.

Equations (1) and (2) have to be complemented with Poisson's equation defining the relation between the potential $\varphi(x)$ and charge density $\rho(x)$ :

$\frac{d^{2} \varphi}{d x^{2}}=-\frac{4 \pi}{\varepsilon} \rho(x)$, 


\section{N. I. Kashirina et al.: Theoretical approach to electrodiffusion...}
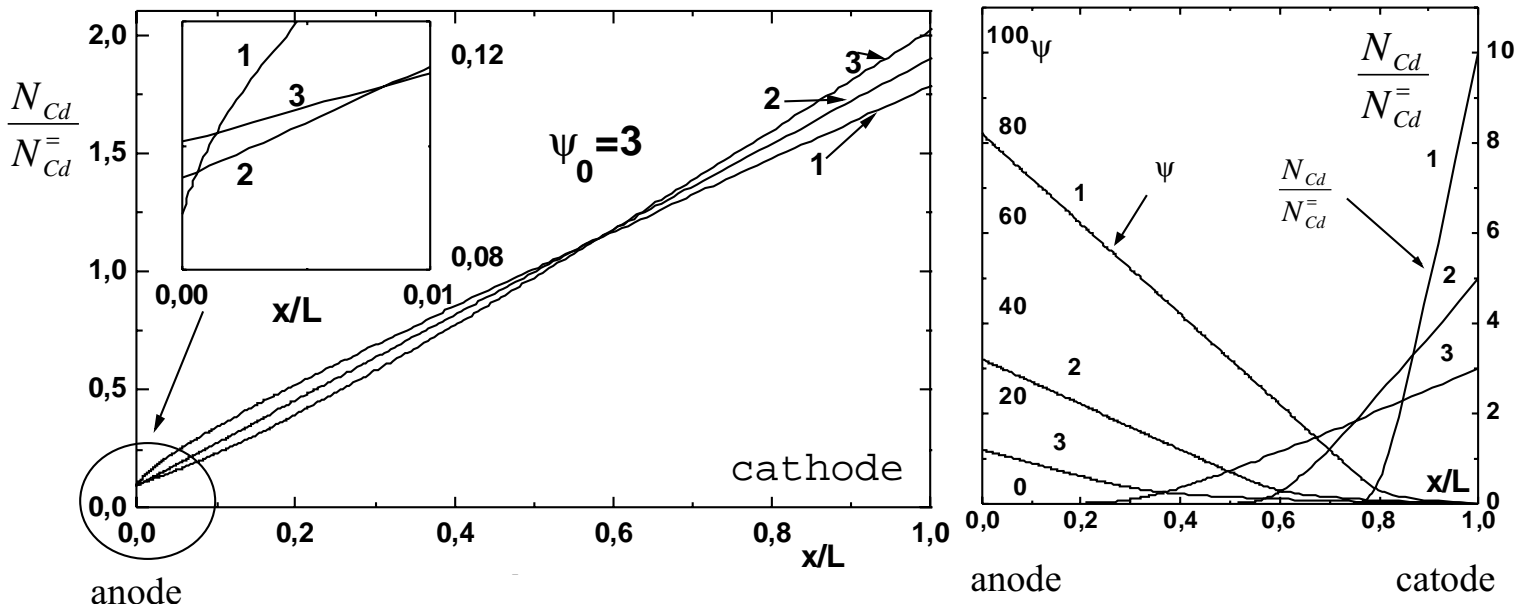

Fig. 1. Redistribution of $\mathrm{Cd}+$ concentration for a system which includes: $(1)$ - three components (electrons $+\mathrm{Cd}_{i}+$ immobile acceptors; $\left.\mathrm{N}_{\mathrm{a}} / \mathrm{N}^{\mathrm{L}} \mathrm{Cd}^{+}=0.1\right) ;(2)$ - two components; (3) - three components (electrons $+\mathrm{Cd}_{\mathrm{i}}+$ immobile donors; $\mathrm{N}_{\mathrm{d}} / \mathrm{N}_{\mathrm{Cd}+}^{\mathrm{L}}=0.1$ ).

Fig. 2. Redistribution of $\mathrm{Cd}^{+}$concentration and voltage (in terms of dimensionless potential $\psi$ ) in the case of positive «background» for various values of current: $1-\mathrm{i} / \mathrm{i}_{0}=$ $=3 ; 2-\mathrm{i} / \mathrm{i}_{0}=5 ; 3-\mathrm{i} / \mathrm{i}_{0}=10$.

where $\rho(x)=e\left(Z_{d} N_{d}+Z_{a} N_{a}-n(x)+N_{C d}^{+}(x)\right)$, (hereinafter $Z_{d}=1 ; Z_{a}=-1$ )

Writing electron density as a function of the potential from equation (1), with Boltzmann's distribution (2) taken into account for the concentration of the mobile $\mathrm{Cd}$ ions, we obtain the integro-differential equation for the dimensionless potential $\psi(x)=e \varphi(x) / k T$ :

$$
\frac{d^{2} \psi}{d x^{2}}=\frac{4 \pi e^{2}}{\varepsilon k T}\left\{\frac{i}{e D_{n}} e^{\psi} \frac{1}{L} \int_{L}^{x} e^{-\psi} d x+n^{(L)} e^{\psi}-N_{C d}^{(L)} e^{-\psi}-\Delta N\right\}
$$

where $i_{0}=e n^{L} D_{n} / L, n^{L}=n(L)$.

The diffusivity $D_{n}$ and mobility $\mu_{n}$ are connected by Einstein's equation.

Equation (5) can be easily rewritten in terms of the electric field:

$$
\begin{aligned}
& \frac{\partial^{2} E}{\partial x^{2}}+\frac{e}{k T} E \frac{\partial E}{\partial x}-\frac{4 \pi e^{2}}{\varepsilon k T} \times \\
& \times\left(2 N_{C d}^{L} e^{-\psi}+\Delta N\right) E+\frac{4 \pi i}{\varepsilon k T} \frac{e}{k T}=0
\end{aligned}
$$

where $\Delta N=N_{d}-N_{a}$.

At $N_{C d}^{L}=0$ eq. (6) transforms into the well-known equation for the field distribution in the space charge region [10]. The presence of mobile donors actually expands the space charge region over Debye's length, determined as:

$L_{D}=\left(\frac{\varepsilon k T}{4 \pi e^{2} \sum_{k} n_{k} Z_{k}^{2}}\right)^{1 / 2}$, where $Z_{k}$ is the charge of $k_{t h}$ component, to the whole length of the crystal.

Equation (6) can be solved by the successive approximation method. As a zero-order approximation, we can take the $N_{C d}(x)$ distribution calculated in the quasi-neutrality approach. Substituting this zero approximation $N_{C d}(x)$ into eq. (6), we can analyze the current-voltage dependence in the first approximation. The convergence of this technique is determined by $L_{D} / L$ ratio.

\section{Results and discussion}

The right side of eq. (5) is zero in the quasi-neutrality approach, and thus we get the potential $\Psi$ as an implicit function in the expression:

$\frac{x}{L}=1-\frac{F(\psi)}{F\left(\psi_{0}\right)}$,

where

$F(\psi)=e^{-\psi}-\frac{\Delta N}{2 N_{C d}^{L}} \psi-1$

Depending on the positive or negative charge of the «background» (corresponding to the sign of $\Delta N),(7)$ tends to behave in essentially different ways. While for $\Delta N \geq 0$ there is a continuous solution of eq. (7) (At $\Delta N=0$ it becomes identical to the expression used in the theory of binary electrolytes [11]), this does not occur if the «background» charge is negative.

In the latter case, the solution has a break, which indicates that the electroneutrality approach is not valid. At any rate, both cases have similar solutions for $\Psi_{0} \leq 3$ (fig. 1). 


\section{N. I. Kashirina et al.: Theoretical approach to electrodiffusion...}

The result obtained for the system with immovable positively charged background is the most attractive, since these conditions allow extending the low $\mathrm{Cd}^{+}$content zone (fig. 2, curves $1,2,3$ correspond to $i / i_{0}=3,5,10$, respectively).

When $i / i_{0}$ value is rather low, the first term in the parentheses in eq. (5) becomes:

$$
\begin{aligned}
& \frac{\partial^{2} \psi}{\partial x^{2}}=\frac{4 \pi e^{2}}{\varepsilon k T} \times \\
& \times\left\{n^{L} e^{\psi}-N_{C d}^{L} e^{-\psi}-\Delta N\right\}
\end{aligned}
$$

which describes the electric field between the plates of a capacitor. Eq. (8) with $\Delta N=0$ and boundary conditions: $\psi(0)=\psi_{0} / 2 ; \psi(L)=-\psi_{0} / 2$ transforms into the Poisson-Boltzman equation:

$$
\frac{\partial^{2} \psi}{\partial x^{2}}=\frac{4 \pi e^{2}}{\varepsilon k T} n^{0}\left\{e^{\psi}-e^{-\psi}\right\}
$$

which is solved analytically for $x \geq 0$ at boundary conditions taken as: $x \rightarrow \propto ; \psi^{\prime} \rightarrow 0$, and the other condition usually determines the value of the field at $x=0$. The value of the field in the sample at $i / i_{0} \sim 0$ is negligible at $\mathrm{x}$ far from the edges of the crystal (fig. 3). The potential distribution within the space charge region (SCR) is determined by the following integral:

$$
\frac{x}{L_{D}}=\int_{\psi}^{\psi_{0} / 2} \frac{d \psi}{\sqrt{e^{\psi}+e^{-\psi}-2}}
$$

A surface charge confined by the external field within a thin $\left(\sim L_{D}\right.$ thickness) within surface layer is calculated by

$$
Q=e L_{D} n_{0} \int_{\psi_{1}}^{\psi_{0} / 2} \frac{\left(e^{\psi}-e^{-\psi}\right) d \psi}{\sqrt{e^{\psi}+e^{-\psi}-2}}
$$

where $\psi_{1}=\psi\left(L_{D}\right) ; e, n_{0}$ are the lectron charge and concentration in the bulk where it equals the donor concentration $N_{C d}^{0}$ and can be obtained from the normality condition:

$$
N_{C d}^{=} L=N_{C d}^{0} \int_{0}^{L} e^{\psi} d x
$$

The right - hand side of eq. (12) contains the total quantity of $\mathrm{Cd}^{+}$ions redistributed in the sample. The term from the left side $N_{C d}$ L determines the number of ions before the electric field was applied, with the uniform initial distribution of the ions taken into account.

Fig. 4 shows that at the potential $\psi_{0}=60-80$ the concentration of mobile defects drops by $3-4$ orders of magnitude (for $L=1 \mathrm{~cm}$ ). Cd ions are confined within a thin layer $\sim 10 L_{D}\left(L_{D}\right.$ - Debye's length, $L_{D}=10^{-5} \mathrm{~cm}$ for $N_{C d}=$ $\left.=10^{15} \mathrm{~cm}^{-3}, \mathrm{~T}=300 \mathrm{~K}\right)$.

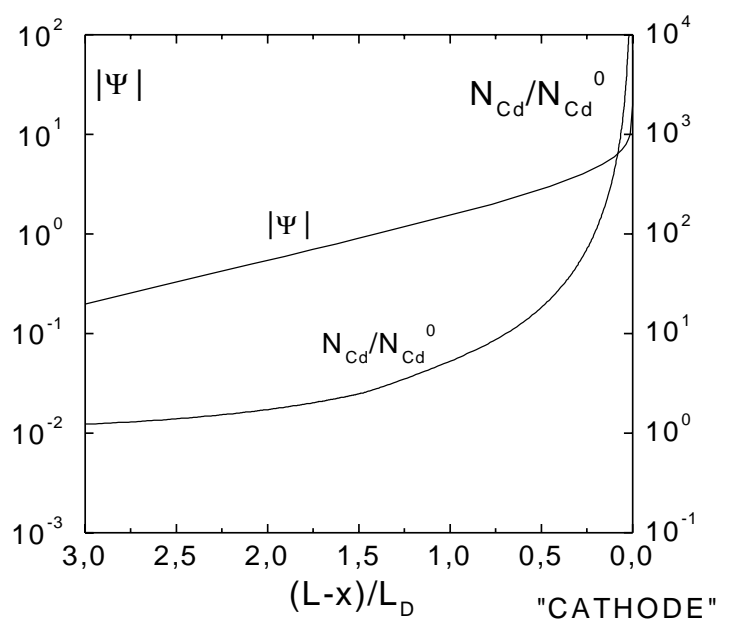

Fig. 3. Distribution of ion concentration and potential of the electric field at $i / i_{0} \sim 0$ (capacitor).

Obviously, $\mathrm{Cd}^{+}$redistribution caused by the external electric field (fig. 4) can be formed by the electric field of a different nature. The capacitance of the space charge layer near the edge of the crystal is associated with the potential $\Psi_{0} / 2$. This potential may originate from a phase interface. Fig. 5 demonstrates the values of the bulk concentration of mobile $\mathrm{Cd}$ which can be reached by the action of the electric field on the metal - CdS interface for various metals. The values of contact barrier heights $\Psi_{\mathrm{b}}$ (in $\mathrm{kT} / \mathrm{e}$ units) were taken from [12]. $\Psi_{\mathrm{b}}$ (in the terms used above) corresponds to $\Psi_{0} / 2$ in formula (10) and in fig. $4 . \mathrm{Cd}^{+}$redistribution presented in fig. 5 is calculated for crystals of length $\mathrm{L}=0.2 \mathrm{~cm}$ under the assumption that one face of a crystal is coated with a metal deposited thereon.

\section{Conclusions}

The possibility is considered to clean out mobile charged defects from the bulk of a crystal by means of the electric field. Calculations are made only for the stationary limit, which can be taken as a boundary condition for the transient problem at $\mathrm{t} \rightarrow \propto$. Hence, our analysis demonstrates the potentialities (determined by the absolute minimum of the system energy) that could be actualized by action of the electric field. The conditions for «cleaning» are most appropriate at $\Delta N>0$, while at $\Delta N<0$ the situation is opposite. The transition from $\Delta N>0$ to $\Delta N<0$ could be reached using band-toband illumination of the crystal. Experimentally, this phenomenon was observed in [8], where the crystal illuminated with UV light was cleaned of mobile defects over the $1 / 4$ of the crystal length.

The Schottky barrier field was found to be effective for reducing the concentration of mobile defects. Calculations were made for various contacting metals. 


\section{N. I. Kashirina et al.: Theoretical approach to electrodiffusion...}

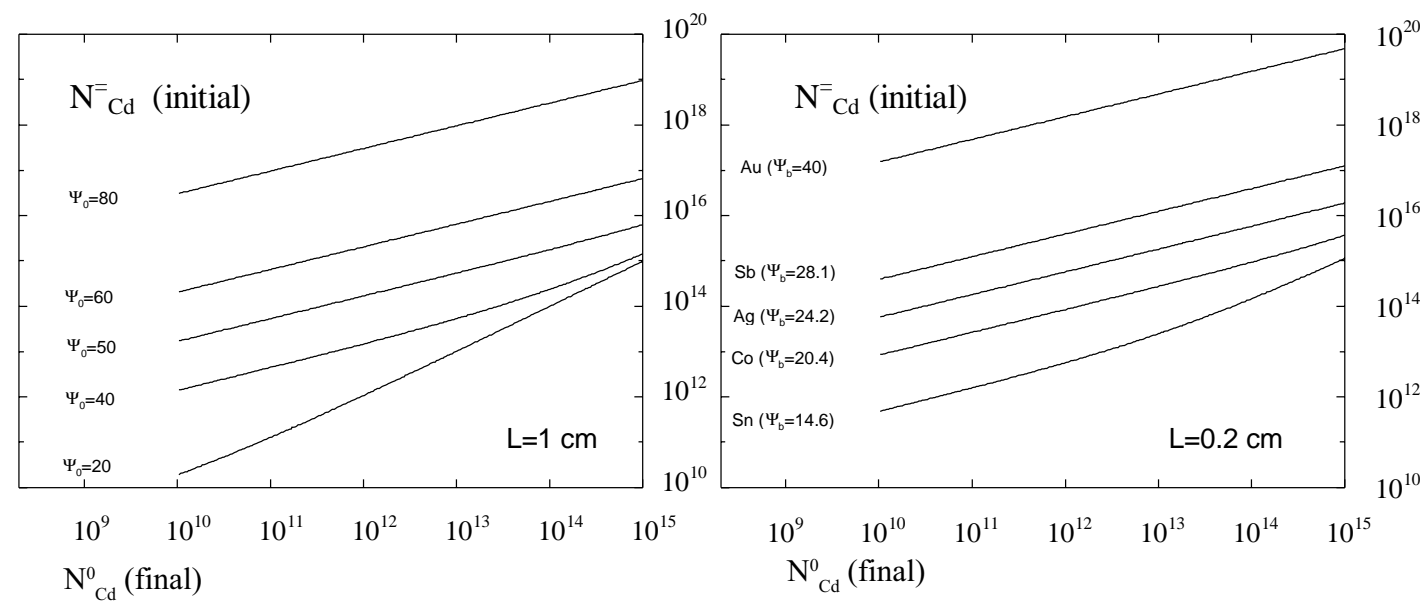

Fig. 4 and 5. Diagrams to determine the anticipated value of the final (stationary) concentration of mobile Cd ions in the bulk ( $\mathrm{N}_{\mathrm{Cd}}^{0}$ ) for a certain value of the initial uniform concentration $\left(\mathrm{N}^{=}{ }_{\text {Cd }}\right)$ at various magnitudes of the external potential $\mathrm{y}_{0}$ applied (Fig. 4 for the case of external electric field) or contact barrier potential yb (Fig. 5 for the case of Schottky barrier potential formed by the deposition of metals $\mathrm{Sn}, \mathrm{Co}, \mathrm{Ag}, \mathrm{Sb}, \mathrm{Au}[12])$. The potential values are presented in $\mathrm{kT} / \mathrm{e}$ units.

\section{Acknowledgments}

The authors would like to thank Prof. N. E. Korsunskaya and Prof. N. B. Lukyanchikova for fruitful discussions and useful remarks.

\section{References}

1. M. K. Sheinkman, N. E. Korsunskaya, Photochemical reactions in II-VI semiconductors. In: Physics of II-VI compounds, ed. by A. N. Georgobiany and M. K. Sheinkman (in Russian), Moscow, Nauka (1986).

2. I. V. Akimov, V. I. Korostelin, I. V. Akimova, V. I. Kozlovskiy, Yu. V. Korostelin, Proc. of Lebedev Inst., 177, p. 142 (1987).

3. I. A. Drozdova, B. Embergenov, N. E. Korsunskaya, I. V. Markevich, A. F. Singaevski, FTP (Soviet Phys. - Semicond., in Russian), 29, p. 536 (1995).
4. A. Oginskas, K. Bertulis, A. Chesnis, N. Shiktorov, Lit. Fiz. Sbornik (Lithuanian Col. Pap.), 21, p. 37 (1981).

5. I. A. Drozdova, B. Embergenov, N. E. Korsunskaya, I. V. Markevich, FTP, 27, p. 630 (1993).

6. A. Zamouche, T. Heiser, A. Mesli, Appl.Phys.Lett., 66, p. 30 (1995).

7. N. E. Korsunskaya, I. V. Markevich, T. V. Torchinskaya, M. K. Sheinkman, FTP, 13, p. 435 (1979).

8. V. V. Kislyuk, N. E. Korsunskaya, I. V. Markevich, G. S. Pekar, M. K. Sheinkman, FTP, 30, p. 884 (1996).

9. V. P. Zlomanov, and A. V. Novoselova, P-T-x Phase Diagrams of MetalChalcogen Systems (in Russian), Nauka Publ., Moscow (1987).

10. V. L. Bonch-Bruyevich, F. D. Kalashnikov, Physics of Semiconductors (in Russian), Nauka Publ., Moscow (1977).

11. J. S. Newman, Electro-Chemical Systems, Prentice-Hall Inc., Englewood Cliffs, NJ (1973).

12. N. M. Forsyth, I. M. Dharmadasa, Z. Sobiesierski, R. H. Williams, Semicond. Sci. Technol., 4, p. 57 (1989).

\section{ТЕОРЕТИЧНИЙ ПІДХІД ДО ЕЛЕКТРОДИФУЗІЇ МІЛКИХ ДОНОРІВ В НАПІВПРОВІДНИКАХ. І. СТАЦІОНАРНИЙ ВИПАДОК}

\section{Н. І. Кашіріна, В. В. Кіслюк, М. К. Шейнкман}

\section{Інститут фізики напівпровідників НАН Украйни}

Резюме. Дається аналіз можливості розподілу рухомих точкових дефектів в напівпровіднику після дії на нього електричного поля до встановлення стаціонарних умов. Розглядаються два способи прикладання напруги: а) безпосередньо до зразка, б) до обкладинок конденсатора, між якими поміщається зразок. Модель також можна застосовувати для електричних полів будь-якої природи - як зовнішніх так і внутрішніх, що виникають, наприклад, на контакті метал-напівпровідник.

\section{ТЕОРЕТИЧЕСКИЙ ПОДХОД К ЕЛЕКТРОДИФФУЗИИ МЕЛКИХ ДОНОРОВ В ПОЛУПРОВОДНИКАХ. І. СТАЦИОНАРНЫЙ СЛУЧАЙ}

\section{Н. И. Каширина, В. В. Кислюк, М. К. Шейкман}

\section{Институт физики полупроводников НАН Украины}

Приводится анализ возможности распределения точечных дефектов в полупроводнике после воздействия на него электрического поля до установления стационарных условий. Рассматривается два способа приложения напряжения: а) непосредственно к образцу, б) к обкладкам конденсатора, между которыми помещается образец. Модель также применима для электрических полей любой природы как внешних так и внутренних, возникающих, например, на контакте металл-полупроводник. 